\title{
STUDENT MISBEHAVIOUR, TEACHER SELF-EFFICACY, BURNOUT AND JOB SATISFACTION: EVIDENCE FROM CROATIA
}

PROBLEMS

OF EDUCATION

IN THE $21^{\text {st }}$ CENTURY

Vol. 79, No. 4, 2021

\author{
Tomislava Vidić \\ Primary School Remete, Croatia \\ E-mail: tomislava.vidic@zg.t-com.hr \\ Marina Đuranović, Irena Klasnić \\ University of Zagreb, Croatia \\ E-mail: marina.duranovic@ufzg.hr, irena.klasnic@ufzg.hr
}

\begin{abstract}
Student misbehaviour is an increasing problem of contemporary school. The aim of this research was to examine the extent to which teachers perceive student misbehaviour, how self-efficient they are, how satisfied they feel with support from their environment and with the teaching job itself, and to which extent they experience the burnout syndrome. The research included 603 primary and secondary school teachers in the Republic of Croatia, and it found quite low, but significant negative correlations between student misbehaviour and teachers'self-efficacy, personal accomplishment, and job satisfaction. Besides, positive correlations between student misbehaviour and teacher burnout were also proven. Statistically significant differences between primary and secondary school teachers were found in their experience of student misbehaviour, dealing with adversities related to student misbehaviour and provided support from expert associates. The results of regression analysis indicate that the overall misbehaviour and satisfaction with help from parents significantly contribute to satisfaction with the teaching profession, and emotional exhaustion and depersonalization lead to decrease of job satisfaction. The results also indicate that demographic characteristics, namely years in service and the type of school, do not contribute to the explanation of neither burnout nor job satisfaction. The implications applicable in practice could relate to the need for preventing student misbehaviour and empowering teachers, regardless of their in-service years and the type of school they work at.
\end{abstract}

Keywords: burnout, classroom management, job satisfaction, quantitative methodology, self-efficacy

\section{Introduction}

\section{Student Misbehaviour}

The goal of education is to decrease unwanted student behaviour and motivate positive and desirable behaviour (Özer et al., 2014). Behaviour can generally be determined as a person's act or reaction fuelled by individual motives and intentions (Johnson, 2003). The range of misbehaviour that students manifest in school on a daily basis is wide (Kulinna et al., 2006). Kulinna et al. (2006) name the following types of misbehaviour: aggressive, illegal or harmful, dodging participation, low engagement or irresponsibility, failing to follow directions, disrespectful misbehaviour, complaining and poor self-management. Based on analysing the literature on student misbehaviour, Sadik and Yalcin (2018) have made the following division: misbehaviour that influences the teaching/learning process and misbehaviour with a negative 
Tomislava VIDIĆ, Marina ĐURANOVIĆ, Irena KLASNIĆ. Student misbehaviour, teacher self-efficacy, burnout and job satisfaction: Evidence from Croatia

PROBLEMS

OF EDUCATION IN THE $21^{\text {st }}$ CENTURY Vol. 79, No. 4, 2021

658

influence on classroom relationships. A major role in manifesting misbehaviour is played by the development period of a child. It is known that in adolescence the young undergo swift and large emotional and physical changes and are more inclined to wrongly perceive a certain situation and, accordingly, react to it inappropriately (Watkins \& Wagner, 2000).

In any case, undisciplined student behaviour in school has a negative influence on both students and teachers. Apart from hindering teachers in teaching (Charles \& Senter, 2012), student misbehaviour has an effect of high school grades, test scores, and graduation and dropout rates (Finn, Fish, \& Scott, 2008). Apart from that, it significantly contributes to the burnout of teachers (Bibou-Nakou et al., 1999; Bradfield i Jones, 1985; Kokkinos, 2007) and can affect the increase of stress in teachers (Tsouloupas et al., 2014). Student misbehaviour can also influence teacher self-efficacy (Hong, 2012), work satisfaction (Kengatharan, 2020) and resigning from the profession (Ingersoll, 2001).

\section{Teacher Self-Efficacy}

Albert Bandura founded the concept of self-efficacy in the 1970-es. Self-efficacy is defined as an individual's belief of being capable to execute certain courses of action necessary in achieving a specific goal, i.e., the belief of possessing the ability to organize and perform actions in a way required for attaining the planned effects (Bandura, 1995; 1997). Self-efficacy belief is related to an individual's ability to discover and manage his or her own abilities (Fidan \& Tuncel, 2021, p. 38). Aelterman et al. (2007) defined teacher's self-efficacy as an extent to which he/she considers they are competent to do their job. Self-efficacy plays an important role in teaching since teachers who perceive themselves as highly self-efficient also consider they can successfully teach students in a very challenging context (Ross et al., 2012). Teachers with a high self-efficacy perception prepare for their work (Wei, 2013), set very high goals for themselves and cooperate better with colleagues and their students' parents (Ross et al., 2012). Such teachers are more willing to try out new teaching methods in order to better satisfy the needs of their students (Fullan, 2014). Self-efficacy beliefs influence the time, devoted effort, and persistence an individual invests in various adverse situation (Bandura, 1997). Bandura also claimed that highly self-efficient individuals are more tenacious and put in greater efforts in order to overcome stressful events and not experience emotional and physical drain. On the other hand, individuals with low self-efficacy beliefs find themselves under greater stress and are less prepared to face the challenging tasks than highly self-efficient individuals.

The sense of self-efficacy presents the teacher's belief in her/his ability to contribute to student learning and development. When teachers feel they contribute to the growth of their students, they are more motivated in the work, which in turn promotes their sense of welfare (Kaynak, 2020). Self-efficacy can increase or decrease an individual's efficacy. The teacher's belief in his/her own self-efficacy is related to his/her behaviour in the classroom (TschannenMoran \& Woolfolk Hoy, 2001). Efficient teachers not only believe they can control student misbehaviour and set appropriate class rules, but also deal with defiant student behaviour (Tschannen-Moran \& Woolfolk Hoy, 2001; Toropova et al., 2021).

\section{Burnout}

In the midst of major overload and the challenges of fulfilling diverse needs of their students, primary and secondary school teachers report a very high level of stress (Herman et al., 2020). Work stress is defined as a series of detrimental physiological, psychological, and behavioural reactions to situations in which work demands are not in accord with the employee's needs and possibilities (Sauter et al., 1990). Chronic stress is tied to burnout, which is characterized by emotional exhaustion, loss of work enthusiasm, alienation, and the sense 
of inadequate achievement (Maslach \& Jackson, 1981; Maslach et al., 2001). Emotional drain entails excessive emotional fatigue (Evers et al., 2004); it manifests as tiredness, loss of energy and lack of work enthusiasm (Schwarzer et al., 2000). Estrangement occurs as a consequence of facing emotional drain and is manifested in negative attitudes, disregard, creating distance between oneself and others (students, colleagues), and indifference to the overall work surroundings (Evers et al., 2004; Maslach et al., 2001).

There are more factors leading to teacher burnout: individual, organizational and transactional. Individual factors include demographic variables such as age, gender, inservice years, personalities, and such. Organizational factors encompass institutional and work characteristics such as inappropriate work demands, administrative support, etc. Finally, transactional factors entail the interaction of individual and organizational factors, such as employees' perceptions of the management style, teacher's attribution of student misbehaviour, etc. (Evers et al., 2004; Friedman, 1995; Maslach \& Jackson, 1981; Maslach et al., 2001).

\section{Job Satisfaction}

Spector (1997) defined job satisfaction as a scope in which people like or dislike their job. Teachers' job satisfaction is delineated by Evans $(1993$, p. 328) as a state of mind determined by the extent to which an individual perceives her/his job-related needs are fulfilled. Klassen and Chiu (2010) emphasise teachers' self-efficacy as an important predictor of job satisfaction. Positive school climate, democratic school management and good, quality cooperation with colleagues may also increase teachers' motivation for the work and their job satisfaction (Durksen et al., 2017; Hurren, 2006). A research by Toropova et al. (2021) has found that working conditions in school are significantly related to teachers' job satisfaction. It was proven, namely, that teacher workload, cooperation between teachers, and student discipline are the most meaningful factors related to teachers' job satisfaction.

Although research on the correlation between teaching and student outcomes is frequent, the issue of teachers' job satisfaction is less often examined. The research on this topic is more pronounced in the last thirty years due to the observed trend of teachers resigning from the profession. Teacher's job satisfaction is a significant predictor of his/her decision whether to remain in the teaching profession (Skaalvik and Skaalvik, 2011).

\section{The Research Aim}

The aim of this research was to examine the extent to which primary and secondary school teachers experience student misbehaviour, how self-efficient they are, how satisfied they are with the support from their environment and the job itself, and in what measure they experience burnout.

With regard to the research aim, the following tasks were set:

a) To examine whether there are differences in perception of the researched variables between teachers working at primary and secondary schools;

b) To determine the extent to which student misbehaviour, self-efficacy in classroom management and satisfaction with provided support contribute to explaining burnout;

c) To determine the extent to which student misbehaviour, self-efficacy in classroom management, satisfaction with the provided support and burnout influence teachers' job satisfaction.

\author{
PROBLEMS \\ OF EDUCATION \\ IN THE $21^{\text {st }}$ CENTURY \\ Vol. 79 , No. 4, 2021 \\ 659
}


Tomislava VIDIĆ, Marina ĐURANOVIĆ, Irena KLASNIĆ. Student misbehaviour, teacher self-efficacy, burnout and job satisfaction: Evidence from Croatia

PROBLEMS

OF EDUCATION

IN THE $21^{\text {st }}$ CENTURY Vol. 79 , No. 4, 2021

660

\section{Research Methodology}

\section{General Background}

This quantitative, exploratory research is directed to teachers' perceptions of student misbehaviour, teachers' self-efficacy, satisfaction with the support from the surroundings and the job itself, as well as burnout.

The initial assumption is that, regardless of their perception of student misbehaviour, teachers will show significant job satisfaction, and they will not have experienced burnout. Although there are numerous problems often pointed out by teachers in the Republic of Croatia, the results of previous research of job satisfaction indicate that, despite everything, teachers are content with their job (Slišković et al., 2016). The differences in teachers' perceptions with regard to the type of school they work at were expected, i.e., primary school teachers would perceive misbehaviour and experience burnout less, whereas they would have greater job satisfaction. Besides, we assumed that teachers would show dissatisfaction with provided support from principals, expert associates, and parents in dealing with and overcoming the problems of student misbehaviour, which in turn contributes to explaining burnout and lower job satisfaction. Along these lines, it was presupposed that student misbehaviour and received support would have a negative effect on explaining job satisfaction and a positive contribution to burnout, while self-efficacy, personal accomplishment and independent problem solving would significantly contribute to teachers' job satisfaction.

The research was implemented anonymously in October 2020, by means of an online questionnaire consisting of 59 claims. The teachers were offered to participate in the research via a closed online group on the social network for teachers working in primary and secondary schools in Croatia.

\section{Participants and Procedures}

The research utilised purposive sampling and included 603 primary and secondary school teachers from the Republic of Croatia. Out of the total number of participants, $71.81 \%(N=433)$ work in primary school and $28.19 \%(N=170)$ in secondary school. It should be stressed that primary school in the Republic of Croatia lasts 8 years and secondary school 4 years, so the participant ratio is acceptable. The collected data about in-service years of the participants show that $39.1 \%$ of them have 0 to 10 of work experience $(n=236), 33.7 \%$ between 11 and 20 years $(n=203), 19.6 \%$ between 21 and 30 years $(n=118)$, and $9.1 \%$ of the teachers have more than 31 years of work experience $(n=46)$. All participants have received their teacher certification from a traditional university preparation program and have passed their state license exams enabling them to work in school. Over $93 \%$ of the participants are of the female sex $(n=562)$, and only $6.8 \%$ are of the male sex $(n=41)$.

\section{Measures}

Student misbehaviour - The types of student misbehaviour were examined with the use of the modified questionnaire Physical Education Classroom Management Instrument (Kulinna et al., 2006). The questionnaire was initially intended to examine student misbehaviour in PE class. In this research, it was implemented with teachers regardless of the subject they teach. The original scale measures eight factors. Factor analysis was implemented with the main components method with orthogonal (varimax) rotation $(\mathrm{KMO}=.967$; Bartlett's test of sphericity $\chi_{d 780}^{2}=22771.71, p<.001$ ). According to the Kaiser-Guttman criterion, after excluding the claims with insufficient factor loading, eight factors had characteristic roots 
over one, but they were not saturated with sufficient number of claims. By reviewing the communalities, it was found that they are often under .70, which means that the factor analysis does not give entirely good factors with this solution. As the criterion of average communality size over .60 was met, i.e., the average communality is .60, and the criterion of the minimal number of participants is over 250 (Field, 2013), the scree plot criterion was applied to review the shape. As the diagram indicated a sudden drop after five factors, the five-factor analysis was implemented and it explained $59.49 \%$ of the misbehaviour variance, with some factors partially matching the factors of the original scale. After the rotation, the first factor, i.e., fails to follow instructions, explains $19.35 \%$ of the overall variance, the second, irresponsible-passive behaviour, explains $13.19 \%$, the third factor, i.e., illegal/harmful behaviour, explains $12.83 \%$ of the variance, the fourth factor (aggressive behaviour) explains $9.12 \%$, and the fifth factor, i.e., irresponsible-aggressive behaviour, explains $4.99 \%$ of the overall student misbehaviour variance. The obtained Cronbach-Alpha reliability coefficients are calculated as follows: $\alpha_{1}=$ $.95 ; \alpha_{2}=.92 ; \alpha_{3}=.88 ; \alpha_{4}=.88 ; \alpha_{5}=.53$. Due to the low reliability coefficient, the fifth factor (irresponsible-aggressive) was excluded from further analyses.

The second part of the student misbehaviour's analysis was implemented based on instructions from the original scale (Kulinna et al., 2003) according to which a group of experts assesses the seriousness of misbehaviour and categorises the types of misbehaviour in the following categories: mild, moderate, or severe. Five selected teachers from primary and secondary schools have classified 59 forms of misbehaviour as follows: 22 types of misbehaviour fall into the mild category (e.g., talking), the moderate category includes 25 types of misbehaviour (e.g., swearing), and the severe category entails 13 types of misbehaviour (e.g., fighting).

Teacher self-efficacy - To measure teachers' self-efficacy in classroom management, Efficacy in Classroom Management dimension was used, adopted from the short form of Teachers' Sense of Efficacy Scale (Tschannen-Moran \& Woolfolk Hoy, 2001). It consists of four claims (e.g., How much can you do to control disruptive behaviour in the classroom?), which the participants assessed on a five-degree scale, from 1 -nothing, to 5 - a great deal. The factor analysis with the main components method with orthogonal (varimax) rotation was used (KMO $=.825 ;$ Bartlett's test of sphericity $\chi_{d f 780}^{2}=1367.06 ; p<.001$ ). According to the Kaiser-Guttman criterion, one factor has a characteristic root higher than $1(3,004)$ and explains $75.11 \%$ of the efficacy variance. The communalities are in range from .71 to .79 . Cronbach's alpha reliability coefficient for efficacy in classroom management subscale was $\alpha=.89(p<.001)$.

Teacher job satisfaction - For measuring teacher job satisfaction, we used the Work Satisfaction dimension, adopted from the questionnaire Abridged Job Descriptive Index (JDI) (Stanton et al., 2001). This dimension consists of five claims (e.g., My work is dull), which the participants assessed by choosing among three possible answers: $0-$ no; 1 - not sure; 3 yes. We implemented the factor analysis with the main components method with orthogonal (varimax) rotation $\left(K M O=.730 ;\right.$ Bartlett's test of sphericity $\left.\chi_{d 7780}^{2}=791.53 ; p<0.001\right)$ which confirmed one-factor solution. According to the Kaiser-Guttman criterion, one factor has a characteristic root above 1 (2.543) and explains $50.86 \%$ of the job satisfaction variance. The communalities are low, i.e., in range from .32 to .66 . Cronbach's alpha reliability coefficient is $\alpha=.75(p<.001)$.

Teacher burnout - To measure teacher burnout, we used the instrument Maslach Burnout Inventory for Educators (MBI-ES) (Maslach et al., 2017). The original questionnaire includes 22 claims that measure 3 burnout dimensions: emotional exhaustion (e.g., I feel emotionally drained from my work), depersonalization (e.g., I've become more callous toward people since I took this job), and personal accomplishment (e.g., I feel I'm positively influencing other people's lives through my work). The participants expressed their agreement with the offered claims on a seven-degree scale, from 0 - never to 6 -every day. The factor analysis with the 
Tomislava VIDIĆ, Marina ĐURANOVIĆ, Irena KLASNIĆ. Student misbehaviour, teacher self-efficacy, burnout and job satisfaction: Evidence from Croatia

PROBLEMS

OF EDUCATION

IN THE $21^{\text {st }}$ CENTURY

Vol. 79 , No. 4,202

662

main components method with orthogonal (varimax) rotation was implemented $(K M O=.906$; Bartlett's test of sphericity $\left.\chi_{d 778}^{2}=6583.95 ; p<.001\right)$. The claim I feel students blame me for some of their problems is excluded from further analysis due to insufficient factor saturation. After the exclusion of this claim, according to the Kaiser-Guttman criterion, three factors have a characteristic root over 1 and together explain $57.96 \%$ of the burnout variance. The obtained Cronbach's alpha reliability coefficients are $\alpha=.93$ for emotional exhaustion, $\alpha=.83$ for depersonalization, and $\alpha=.70$ for personal accomplishment $(p<.001)$.

Dealing with problems and satisfaction with provided support - In order to find out who teachers most frequently turn to when they need help and support in dealing with student misbehaviour and how satisfied they are with the given help, two questions were used: Who do you most frequently turn to for help in dealing with student misbehaviour; How satisfied are you with the provided help (how useful was it)? The participants were offered the following source of help: I deal with the problem myself; For help, I turn to teacher colleagues, expert associates, school principal, parents. The frequency of asking for help was assessed on a scale from 1 - never to 5 - very often, i.e., from 1 - useless to 5 - very useful. The calculated Cronbach's alpha reliability coefficient for the claims is $\alpha=.65(p<.001)$.

\section{Research Results}

Results based on the descriptive statistics for the used variables are presented in Table 1. These data show that the obtained average values of student misbehaviour shifted toward higher values in fails to follow instructions and irresponsible passive behaviour, i.e., mild forms of misbehaviour were assessed with higher values, while moderate forms of misbehaviour were assessed with somewhat lesser and severe with the lowest values. The data indicate somewhat higher values of the perception of self-efficacy in class management and high assessment of teachers' job satisfaction. Along these lines, teachers assessed their personal accomplishment highly; they assigned low values to experiencing emotional exhaustion and very low values to depersonalization. The obtained values in the category of asking for help revealed that the teachers mostly relied on themselves in solving problems of student misbehaviour, followed by seeking help from expert associates, students' parents and colleagues, while they asked for help from the school principal the least. The assessment of satisfaction with provided help shows that the examined teachers are most satisfied with help and support from colleagues, somewhat less with support from expert associates and the least with help from principals and parents. 
Tomislava VIDIĆ, Marina ĐURANOVIĆ, Irena KLASNIĆ. Student misbehaviour, teacher self-efficacy, burnout and job satisfaction: Evidence from Croatia

PROBLEMS

OF EDUCATION

IN THE $21^{\text {st }}$ CENTURY

Vol. 79, No. 4, 2021

663

Descriptive Statistics for the Observed Variables $(N=603)$

\begin{tabular}{|c|c|c|c|c|c|c|}
\hline Dimension & $M$ & $S D$ & $\begin{array}{c}\text { Obtained } \\
\text { range }\end{array}$ & $\begin{array}{c}\text { Theoretical } \\
\text { range }\end{array}$ & Skewness & Kurtosis \\
\hline Misbehaviour - total & 2.65 & 0.61 & $1.07-4.83$ & $1-5$ & .237 & -.045 \\
\hline $\begin{array}{l}\text { Fails to follow } \\
\text { instructions }\end{array}$ & 3.30 & 0.78 & $1.00-5.00$ & $1-5$ & -.094 & -.470 \\
\hline Irresponsible - passive & 3.02 & 0.77 & $1.00-5.00$ & $1-5$ & .073 & -.297 \\
\hline Illegal/harmful & 2.01 & 0.62 & $1.00-5.00$ & $1-5$ & .866 & .939 \\
\hline Aggressive & 2.46 & 0.72 & $1.00-5.00$ & $1-5$ & .360 & -.299 \\
\hline Mild & 3.20 & 0.68 & $1.19-5.00$ & $1-5$ & -.110 & -.334 \\
\hline Moderate & 2.69 & 0.68 & $1.04-4.96$ & $1-5$ & .295 & -.124 \\
\hline Severe & 1.76 & 0.53 & $1.00-4.69$ & $1-5$ & 1.244 & 2.658 \\
\hline Self-efficacy & 3.93 & 0.61 & $1.00-5.00$ & $1-5$ & -.524 & 1.312 \\
\hline Job satisfaction & 2.56 & 0.65 & $0.00-3.00$ & $0-3$ & -1.655 & 2.341 \\
\hline Burnout - total & 2.79 & 0.77 & $0.50-5.73$ & $0-6$ & .276 & .387 \\
\hline Emotional Exhaustion & 2.61 & 1.48 & $0.00-6.00$ & $0-6$ & .284 & -.756 \\
\hline $\begin{array}{l}\text { Personal } \\
\text { Accomplishment }\end{array}$ & 4.09 & 1.06 & $0.75-6.00$ & $0-6$ & -.540 & -.005 \\
\hline Depersonalization & 1.02 & 1.11 & $0.00-6.00$ & $0-6$ & 1.361 & 1.654 \\
\hline \multicolumn{7}{|l|}{ Solve problem } \\
\hline $\begin{array}{l}\text { Independent problem } \\
\text { solving }\end{array}$ & 4.26 & 0.80 & $1.00-5.00$ & $1-5$ & -.962 & .815 \\
\hline Colleague & 3.06 & 0.91 & $1.00-5.00$ & $1-5$ & .050 & -.294 \\
\hline Expert associates & 3.26 & 0.98 & $1.00-5.00$ & $1-5$ & .149 & -.514 \\
\hline School Principal & 2.30 & 1.04 & $1.00-5.00$ & $1-5$ & .609 & -.031 \\
\hline Parents & 3.16 & 1.10 & $1.00-5.00$ & $1-5$ & -.017 & -.675 \\
\hline \multicolumn{7}{|l|}{ Satisfaction with } \\
\hline Colleague & 3.55 & 1.21 & $1.00-5.00$ & $1-5$ & -.523 & -.620 \\
\hline Expert associates & 3.21 & 1.27 & $1.00-5.00$ & $1-5$ & -.256 & -.925 \\
\hline School Principal & 2.83 & 1.38 & $1.00-5.00$ & $1-5$ & .087 & -1.246 \\
\hline Parents & 2.82 & 1.06 & $1.00-5.00$ & $1-5$ & .023 & -.489 \\
\hline
\end{tabular}

The analysis of the obtained individual results has shown that the most frequent types of student misbehaviour are: talking $(M=4.00 ; S D=0.94)$, not following directions $(M=3.57$; $S D=1.00)$, giggling $(M=3.57 ; S D=1.06)$, arguing $(M=3.48 ; S D=1.01)$, laziness $(M=3.48$; $S D=1.04)$. On the other hand, amongst the rarest forms of misbehaviour are bringing weapons to class $(M=1.13 ; S D=0.41)$ and drug use $(M=1.27 ; S D=0.59)$.

Since the primary task of this research was to establish the contribution of misbehaviour, self-efficacy and the support to explaining burnout, i.e., satisfaction with teaching, Pearson correlation coefficients were calculated before the implementation of the regression analyses. The obtained values of the correlations are shown in Table 2. 
Tomislava VIDIĆ, Marina ĐURANOVIĆ, Irena KLASNIĆ. Student misbehaviour, teacher self-efficacy, burnout and job satisfaction: Evidence from Croatia

\author{
PROBLEMS \\ OF EDUCATION \\ IN THE $21^{\text {st }}$ CENTURY \\ Vol. 79 , No. 4, 2021 \\ Table 2 \\ Correlations among the Observed Variables in the Study
}

\begin{tabular}{|c|c|c|c|c|c|c|c|c|c|c|c|}
\hline & 1 & 2 & $2 a$ & $2 b$ & 2c & $2 d$ & 3 & 4 & 5 & $5 a$ & $5 b$ \\
\hline 1. Work experience & - & & & & & & & & & & \\
\hline 2. Misbehaviour - Total &,- 06 & - & & & & & & & & & \\
\hline 2a. Fails to follow instruction & -.09 & $.92^{*}$ & - & & & & & & & & \\
\hline 2b. Irresponsible - passive & .02 & $.93^{*}$ & $.82^{*}$ & - & & & & & & & \\
\hline 2c. Illegal/harmful & -.01 & $.76^{\star}$ & $.53^{*}$ & $.70^{*}$ & - & & & & & & \\
\hline 2d. Aggressive & .02 & $.84^{*}$ & $.75^{\star}$ & $.73^{*}$ & $.52^{*}$ & - & & & & & \\
\hline 3. Self-efficacy & $.17^{*}$ & $-.18^{*}$ & $-.22^{*}$ & $-.11^{*}$ & -.07 & $-.18^{*}$ & - & & & & \\
\hline 4. Job satisfaction & -.01 & $-.23^{*}$ & $-.21^{*}$ & $-.21^{*}$ & $-.22^{*}$ & $-.16^{*}$ & $.24^{*}$ & - & & & \\
\hline 5. Burnout - Total & .03 & $.32^{*}$ & $.30^{*}$ & $.31^{*}$ & $.23^{*}$ & $.24^{*}$ & -.06 & $-.34^{*}$ & - & & \\
\hline 5a. Emotional exhaustion & .04 & $.37^{*}$ & $.35^{\star}$ & $.35^{*}$ & $.35^{*}$ & $.27^{\star}$ & $-.23^{*}$ & $-.22^{*}$ & $-.50^{*}$ & - & \\
\hline 5b. Personal accomplishment & .04 & $-.09^{* *}$ & $-.09^{* *}$ & -.06 & -.07 & -.08 & $.38^{*}$ & $.35^{*}$ & $.28^{*}$ & $-.21^{*}$ & - \\
\hline 5c. Depersonalization & -.08 & $.19^{*}$ & $.19^{*}$ & $.17^{\star}$ & $.13^{*}$ & $.16^{*}$ & $-.22^{*}$ & $-.39^{*}$ & $.60^{*}$ & $.49^{*}$ & $-.16^{*}$ \\
\hline
\end{tabular}

Although the calculated correlations are quite low, there is a significant negative correlation of student misbehaviour and teachers' self-efficacy, personal accomplishment, and job satisfaction. Student misbehaviour is significantly positively correlated to teacher burnout. Self-efficacy in classroom management is in significant positive correlation with job satisfaction and personal accomplishment and in negative correlation with emotional exhaustion and depersonalization.

Work experience is positively correlated only with teacher self-efficacy. Therefore, teachers with more work experience assessed themselves as more competent in classroom management. Expectedly, significant negative correlation between burnout and job satisfaction was found, i.e., emotional exhaustion and depersonalization, while personal accomplishment is positively correlated to job satisfaction.

The next research task was to examine the existence of differences in the perception of the research variables among primary and secondary school teachers.

The implementation of Student's t-test found statistically significant differences in dimensions of students' misbehaviour, wherein primary school teachers, in comparison to secondary school teachers, experience some forms of misbehaviour more, namely fails to follow instructions $(t=2.43, p<.01)$ and aggressive behaviour $(t=5.75, p<.01)$. On the contrary, secondary school teachers are statistically significantly different from primary school teachers in their experience of illegal harmful misbehaviour $(t=-11.33, p<.01)$ and severe misbehaviour in general $(t=-3.78, p<.01)$.

When compared to secondary school teachers, primary school teachers independently solve problems related to student misbehaviour statistically significantly more $(t=2.20, p<.01)$ and are less satisfied with the provided support from expert associates $(t=-2.26, p<.01)$.

No statistically significant differences were found between primary and secondary school teachers in the perception of self-efficacy, burnout, and job satisfaction. 
Tomislava VIDIĆ, Marina ĐURANOVIĆ, Irena KLASNIĆ. Student misbehaviour, teacher self-efficacy, burnout and job satisfaction: Evidence from Croatia

PROBLEMS

OF EDUCATION

IN THE $21^{\text {st }}$ CENTURY

Vol. 79, No. 4, 2021

Regression analysis was done in order to ascertain separate contributions of student misbehaviour, independent problem solving, satisfaction with provided support and selfefficacy to explaining teacher burnout. Apart from the previously checked correlations between the variables, elements that needed to be fulfilled before implementing the regression analysis were also verified. The results show that, although not all variables are normally distributed, the distributions are not bimodal nor $\mathrm{U}$ distributions, and that they are mostly symmetrical. Besides, the unexplained part of the criterion variance (residuals) is distributed normally. Durbin-Watson test is around 2 (2.010), i.e., it does not indicate the existence of multicollinearity, and the same is found by VIF factors, which are under 4 (from 1.004 to 1.665).

In Table 3, the results of regression analysis are presented that show the regression coefficient of $R=0.373$, i.e., $13.9 \%$ of the explained burnout variance based on the introduced predictors.

\section{Table 3}

\section{Regression Analysis of Burnout Predictors}

\begin{tabular}{|c|c|c|c|c|}
\hline & $\Delta \mathbf{R}^{2}$ & $\beta$ & $t$ & $p$ \\
\hline \multicolumn{5}{|l|}{1} \\
\hline Work experience & & .035 & .863 & .389 \\
\hline Type of school & & -.041 & -.994 & .321 \\
\hline \multicolumn{5}{|c|}{$R=0.052 ; R^{2}=0.002 ;$ adjusted $R^{2}=-0.001 ; \Delta F(2 / 600)=0.814 ; p>0.05$} \\
\hline
\end{tabular}

2 $.137^{* *}$

Misbehaviour

.297

.061

$-.127$

$-.047$

Satisfaction with support from the school principal

Satisfaction with support from parents

Self-efficacy

Satisfaction with support from teacher colleagues
7.548

.000

1.557

.120

$\mathrm{R}=0.373 ; \mathrm{R}^{2}=0.139 ;$ adjusted $\mathrm{R}^{2}=0.126 ; \Delta \mathrm{F}(7 / 593)=13.464 ; \mathrm{p}<0.001$

Note. $\beta$-standardized regression coefficient, $\Delta \mathrm{R} 2=$ adjusted coefficient of determination, adjusted $\mathrm{R} 2=$ adjusted coefficient of determination according to the number of variables in the model; $* p<.05 ; * * p<.01$

The first regression analysis step shows that work experience and the type of school (primary/secondary school) do not contribute to explaining burnout. The obtained regression coefficient is not statistically significant. In the second step, the overall misbehaviour, solving the related problems, satisfaction with support from others and self-efficacy were added to the analysis. The percentage of the explained burnout variance was increased by $13.7 \%$ and is $13.9 \%(R=0.373)$. The increase in the percentage of the explained variance is statistically significant $(F=13.464 ; p<.001)$. Significant predictors are overall misbehaviour $(\beta=.297$; $t=7.548 ; p<.01)$, satisfaction with help from expert associates $(\beta=-.127 ; t=-2.612 ; p<$ $.01)$. Other variables do not have independent contribution to the burnout explanation. The increased result on overall misbehaviour leads to the increase of burnout, while higher result on satisfaction with help from expert associates leads to the decrease of burnout. Additional analyses show that the portion of the explained burnout variance via misbehaviour is $9 \%$, 
Tomislava VIDIĆ, Marina ĐURANOVIĆ, Irena KLASNIĆ. Student misbehaviour, teacher self-efficacy, burnout and job satisfaction: Evidence from Croatia

PROBLEMS

OF EDUCATION

IN THE $21^{\text {st }}$ CENTURY Vol. 79 , No. 4,202

and by satisfaction with help from expert associates $2 \%$. All other proportions of the burnout variance explanations are very low.

The next regression analysis was implemented in order to examine the contribution of the variables to explaining teachers' job satisfaction. Apart from checking the correlation between the variables, elements that needed to be satisfied in order to utilize the regression analysis were checked. The results show that, although all variables are not normally distributed, the distributions are not bimodal nor $U$ distributions, and they are mostly symmetrical. Besides, the unexplained part of the criterion variance (residuals) is distributed normally. Durbin-Watson test is around 2 (2.057), that is, it does not indicate the existence of multicollinearity, and the same is found by VIF factors, which are under 4 (from 1.004 to 1.675).

Table 4 presents the results of the regression analysis, which provide information on the regression coefficient $R=0.605$, i.e., on the $36.6 \%$ of the explained job satisfaction variance based on the introduced predictors.

Table 4

Regression Analysis of Job Satisfaction Predictors

\begin{tabular}{|c|c|c|c|}
\hline & $\beta$ & $t$ & $p$ \\
\hline \multicolumn{4}{|l|}{1} \\
\hline Work experience & -.003 & -.074 & .941 \\
\hline Type of school & -.063 & -1.536 & .125 \\
\hline \multicolumn{4}{|c|}{$R=0.063 ; R^{2}=0.004 ;$ adjusted $R^{2}=0.001 ; \Delta F(2 / 600)=1.195 ; p>0.05$} \\
\hline 2 & & & \\
\hline Misbehaviour & -.032 & -.898 & .370 \\
\hline Independent problem solving & .029 & .860 & .390 \\
\hline Satisfaction with support from teacher colleagues & .038 & .965 & .335 \\
\hline Satisfaction with support from expert associates & .035 & .823 & .411 \\
\hline Satisfaction with support from the school principal & .025 & .584 & .559 \\
\hline Satisfaction with support from parents & .085 & 2.246 & .025 \\
\hline Self-efficacy & .004 & .114 & .909 \\
\hline Emotional Exhaustion & -.337 & -8.232 & .0001 \\
\hline Personal Accomplishment & .221 & 6.058 & .0001 \\
\hline Depersonalization & -.154 & -4.003 & .0001 \\
\hline \multicolumn{4}{|c|}{$R=0.605 ; R^{2}=0.366 ;$ adjusted $R^{2}=0.353 ; \Delta F(9 / 590)=33.632 ; p<0.001$} \\
\hline
\end{tabular}

The first regression analysis step shows that work experience and the type of school (primary/secondary) do not contribute to explaining job satisfaction. The obtained regression coefficient is not statistically significant. In the second step, we added into the analysis the overall misbehaviour, independent problem solving, satisfaction with support from others, the burnout dimension and self-efficacy. The percentage of the explained job satisfaction variance has risen to $36.2 \%$ and is $36.6 \%(R=0.605)$. The increase of the explained variance percentage is statistically significant $(F=33.632 ; p<.001)$. Significant predictors are the following: satisfaction with help from parents $(\beta=.085 ; t=2.246 ; p<.01)$, emotional exhaustion $(\beta$ $=-.337 ; t=-8.232 ; p<.01)$, personal accomplishment $(\beta=.221 ; t=6.058 ; p<.01)$ and depersonalization $(\beta=-.154 ; t=-4.003 ; p<.01)$. Other variables do not have independent 
contribution to explaining job satisfaction. The increased results on the satisfaction with support from parents and personal accomplishment lead to the rise in job satisfaction, while the enlarged results in emotional exhaustion and depersonalization lead to the decrease of job satisfaction. Additional analyses reveal that the proportion of the explained job satisfaction variance through satisfaction with parental support is $2 \%$, based on emotional exhaustion $17 \%$, personal accomplishment $8 \%$, and based on depersonalization $6 \%$. All other proportions of the job satisfaction variance are very low.

\section{Discussion}

The purpose of this quantitative research was to examine the measure to which teachers experience student misbehaviour, how efficient they are, how satisfied with the support from their surroundings and the work itself, as well as to which extent they experience burnout.

Student misbehaviour hinders the teaching process and classroom management, and the obtained results indicate that the teachers have assessed the mild forms of misbehaviour with higher values. Considering the prevalence of student misbehaviour, according to the teachers' assessments, Sun and Shek (2012) singled out 17 categories, wherein doing something in private was proven to be the most frequent, followed by talking out of turn (particularly in the form of disruptive conversation). The teachers were probably directed to these types of behaviour because they hinder or even disable the learning/teaching process for disruptive students themselves, other students in class and teachers. Quality instruction implies conversation, communication, and interaction; however, the implied conversation may not disturb the realization of the teaching goal in any way.

The results of this research have confirmed the positive correlation between student misbehaviour and teacher burnout and are in line with prior studies which show that teachers assess student misbehaviour as extremely stressful (Aloe et al., 2014; Kyriacou, 2011). Furthermore, it was determined in this study that the teachers who perceive themselves as efficient are satisfied with their job and declare higher personal achievement and less emotional exhaustion and depersonalization. Numerous research studies in literature confirm the positive influence of teacher self-efficacy on job satisfaction (Demir, 2020; Kasalak \& Dağyar, 2020; Soto \& Rojas, 2019). The obtained results are in accord with the data obtained from the synthesis of 40 years of research according to which, amongst others, teacher self-efficacy is positively correlated with personal accomplishment and job satisfaction, while teacher burnout is in correlation with a decrease in teacher efficacy (Zee \& Koomen, 2016). Some previous research studies confirm high job satisfaction among teachers in Croatia (Slišković et al., 2016), and they are above average in relation to the average satisfaction rates of teachers who participated in the TALIS project (Braš Roth et al., 2014). The negative correlation between exhaustion and depersonalization and teacher efficacy is also corroborated by research of other authors (Skaalvik \& Skaalvik, 2010; Savas et al., 2014). Negative influence of low teacher self-efficacy on burnout is present amongst teachers working at different levels of education (Savas et al., 2014).

The results also indicate that, in relation to primary school students, secondary school students are less prone to mild forms of misbehaviour. The obtained statistically significant differences in the dimensions of severe misbehaviour (illegal/harmful, aggressive, severe) indicate they are more frequent among secondary school students but are present the least when compared to other forms of misbehaviour. It is possible to assume that such results are a consequence of applying school and legal acts. Namely, the practice shows that severe forms of misbehaviour are sanctioned, and students are being warned, reprimanded and even excluded from school. On the other hand, mild forms of misbehaviour are more frequently regulated in class by less severe forms of punishment, such as warnings and alike, and they depend

\begin{tabular}{|l} 
PROBLEMS \\
OF EDUCATION \\
IN THE 21 $1^{\text {st }}$ CENTURY \\
Vol. 79, No. 4, 2021 \\
\hline 667
\end{tabular} 
Tomislava VIDIĆ, Marina ĐURANOVIĆ, Irena KLASNIĆ. Student misbehaviour, teacher self-efficacy, burnout and job satisfaction: Evidence from Croatia

PROBLEMS

OF EDUCATION IN THE $21^{\text {st }}$ CENTURY Vol. 79, No. 4, 2021

668

on the teacher's competence in classroom management. It is possible that students, knowing they are in no danger of being sanctioned, which in turn jeopardises their school achievement or the continuation of their education, proceed with mild forms of misbehaviour. Scientific literature does not fully explain the relationship between student misbehaviour and the grade they attend (Lopes et al., 2017). Besides, considering the wide spectrum of developmental changes, challenges and pressures, there are probably diverse reasons for student misbehaviour (Johnson et al., 2018). More recent research confirms that students in puberty have low selfefficacy, which is reflected in their school achievement (Martin \& Steinbeck, 2017), and they are more prone to delinquent forms of behaviour (Chen \& Astor, 2009). It is possible to assume that developmental changes are the cause of results obtained in this research as well. Similar results were found in an earlier research too (Ljubin Golub et al., 2016).

In the present research, primary school teachers have shown greater autonomy in solving problems of student misbehaviour probably because they encounter mild forms of student misbehaviour more often and subsequently solve the related problems independently. On the other hand, secondary school teachers were more satisfied with provided help from expert associates. It is possible that student misbehaviour in secondary school is more frequently sanctioned on the school level, which makes help from expert associates indispensable. Such results are in line with an earlier research done by Betoret (2009) in Spain.

This study showed that work experience and the type of school (primary/secondary school) do not contribute to explaining burnout. After they had implemented a research in Israel, Gavish and Friedman (2010) asserted that teacher beginners can have a high burnout level, even higher than older colleagues. As a possible cause, they state that many started experiencing burnout as early as in the course of their education, i.e., preparation for the teacher calling. Previous research has pointed out that secondary school teachers experience a higher level of burnout than primary school teachers do. However, today the attention of researchers is directed to characteristics of teachers in lesser extent, while they are more focused on the effects of school factors on teacher burnout (Aloe et al., 2014). In the current study, the differences in the participants' experience of burnout according to work experience and the type of school they work in have not been found. The lack of social support in the workplace is one of the most frequent reasons of teacher burnout (Greenglass et al., 1994). Conversely, the increased perception of social support in the workplace can protect teachers form burnout (Kahn et al., 2006; Ju et al., 2015).

Finally, in this research, all three burnout dimensions significantly explain the measure in which teachers are satisfied with their job. Skaalvik and Skaalvik (2010) obtained similar results in their research. The authors established that emotional exhaustion and depersonalization are connected with lower job satisfaction of teachers, wherein emotional exhaustion was proven as the most powerful predictor, which is also the case in our research. Besides, in this research, support from parents was proven as a significant predictor of teacher job satisfaction. Previous research also stresses the importance of teacher-parent relationships (Darmody \& Smyth, 2010; El-Hilali \& Al-Rashidi, 2015).

In order to gain better understanding of teacher burnout, self-efficacy and job satisfaction, future research should differentiate between various dimensions of the stated constructs, and longitudinal studies could be an appropriate approach (Skaalvik \& Skaalvik, 2010).

\section{Conclusions and Implications}

This work contributes to better understanding of the measure in which teachers experience student misbehaviour, how self-efficient and satisfied they are with support from their environment and the job itself, and to which measure they experience burnout in the Croatian school context at different education levels, namely primary and secondary. 
According to the teachers' assessments, the most frequent types of student misbehaviour IN THE $21^{\text {st }}$ CENTURY from the severe category. It was found that student misbehaviour is in significant correlation to teacher burnout, while it is in low negative correlation with teacher self-efficacy, personal accomplishment, and job satisfaction. According to the type of school, when compared to secondary school teachers, primary school teachers more often perceive mild and moderate forms of student misbehaviour, with the difference being statistically significant. Furthermore, they overcome the problems of student misbehaviour more independently and are less satisfied with the provided support from expert associates. The results of the regression analysis indicate that significant predictors of independent contribution to explaining burnout are overall student misbehaviour, whose increased result leads to intensifying burnout, and satisfaction with provided help from expert associates, whose enlarged result contributes to burnout reduction. The variables with independent influence on explaining the increase of job satisfaction are support from parents and personal accomplishment; on the other hand, emotional exhaustion and depersonalization have an independent influence on explaining the dampening of job satisfaction. In the three-dimensional burnout model, emotional exhaustion was proven as the most significant predictor of teacher burnout. Finally, this study points out that, regarding burnout, contextual variables (overall misbehaviour and satisfaction with help from expert associates) have greater predictive value, whereas personality characteristics explain job satisfaction variances more.

The results show that demographic characteristics, work experience and the type of school do not contribute to explaining neither burnout nor job satisfaction. Applicable implications in practice could relate to the need for preventing student misbehaviour and empowering teachers, regardless of the length of their work experience or type of school they work in.

\section{Declaration of Interest}

Authors declare no competing interest.

\section{References}

Aelterman, A., Engels, N., Petegem, K. V., \& Verhaeghe, J. P. (2007). The well-being of teachers: The importance of a supportive school culture. Educational Studies, 33(3), 285-297. https://doi.org/10.1080/03055690701423085

Aloe, A. M., Shisler, S. M., Norris, B. D., Nickerson, A. B., \& Rinker, T. W. (2014). A multivariate meta-analysis of student misbehaviour and teacher burnout. Educational Research Review, 12(1), 30-44. https://doi.org/10.1016/j.edurev.2014.05.003

Bandura, A. (1995). Exercise of personal and collective efficacy in changing societies. In A. Bandura, Self-efficacy in Changing Societies (pp. 1-45). Cambridge University Press.

Bandura, A. (1997). Self-efficacy: The exercise of control. Freeman.

Betoret, F. D. (2009). Self-efficacy, school resources, job stressors and burnout among Spanish primary and secondary school teachers: A structural equation approach. Educational Psychology, 29(1), 45-68. https://doi.org/10.1080/01443410802459234

Bibou-Nakou, I., Stogiannidou, A., \& Kiosseoglou, G. (1999). The relation between teacher burnout and teachers' attributions and practices regarding school behavioural problems. School Psychology International, 20(2), 209-217. https://doi.org/10.1177/0143034399020002004

Bradfield, R., \& Jones, D. (1985). Stress and the Special Teacher: How bad is it? Academic Therapy, 20(5), 571-577. https://psycnet.apa.org/record/1985-23697-001

Braš Roth, M., Markočić Dekanić, A., \& Ružić, D. (2014). TALIS 2013: Glas učitelja i ravnatelja za bolje ishode poučavanja [TALIS 2013: The voice of teachers and principals for better teaching outcomes]. Nacionalni Centar za vanjsko vrednovanje obrazovanja.

Charles, C. M., \& Senter, G. W. (2012). Elementary classroom management (6th Ed.). Pearson. 
Tomislava VIDIĆ, Marina ĐURANOVIĆ, Irena KLASNIĆ. Student misbehaviour, teacher self-efficacy, burnout and job satisfaction: Evidence from Croatia

PROBLEMS

OF EDUCATION IN THE $21^{\text {st }}$ CENTURY Vol. 79 , No. 4,2021

670

Chen, J.-K., \& Astor, R. A. (2009). Students' reports of violence against teachers in Taiwanese schools. Journal of School Violence, 8(1), 2-17. https://doi.org/10.1080/15388220802067680

Darmody, M., \& Smyth, E. (2010). Job satisfaction and occupational stress among primary school teachers and school principals in Ireland. The Teaching Council and ESRI.

Demir, S. (2020). The role of self-efficacy in job satisfaction, organizational commitment, motivation, and job involvement. Eurasian Journal of Educational Research, 20(85), 205 - 224. https://doi.org/10.14689/ejer.2020.85.10

Durksen, T., Klassen, R. M., \& Daniels, L. (2017). Motivation and collaboration: The keys to a developmental framework for teachers' professional learning. Teaching and Teacher Education, 67, 53-66. https://doi.org/10.1016/j.tate.2017.05.011

El-Hilali, N., \& Al-Rashidi, L. (2015). The impact of parental involvement, personality traits and organizational support on satisfaction. Procedia - Social and Behavioral Sciences, 177, 408-419. https://doi.org/10.1016/j.sbspro.2015.02.382

Evans, L. (1993). Addressing problems of conceptualization and construct validity in researching teachers' jobsatisfaction.EducationalResearch,39(3),319-331.https://doi.org/10.1080/0013188970390307

Evers, W. J. G., Tomic, W., \& Brouwers, A. (2004). Burnout among teachers: Students' and teachers' perceptions compared. School Psychology International, 25(2), 131-148. https://doi.org/10.1177/0143034304043670

Fidan, M., \& Tuncel, M. (2021). Developing a self-efficacy scale toward physics subjects for lower-secondary school students. Journal of Baltic Science Education, 20(1), 38-49. https://doi.org/10.33225/jbse/21.20.38

Field, A. (2013). Discovering Statistics Using IBM SPSS Statistics (4th Ed.). SAGE.

Finn, J. D., Fish, R. M., \& Scott, L. A. (2008). Educational sequelae of high school misbehaviour. The Journal of Educational Research, 101(5), 259-274. https://doi.org/10.3200/JOER.101.5.259-274

Friedman, I. A. (1995). Student behaviour patterns contributing to teacher burnout. The Journal of Educational Research, 88(5), 281-289. https://doi.org/10.1080/00220671.1995.9941312

Fullan, M. (2014). The principal: Three keys to maximizing impact. Josey Bass.

Gavish, B., \& Friedman, I. A. (2010). Novice teachers' experience of teaching: A dynamic aspect of burnout. Social Psychology of Education: An International Journal, 13(2), 141-167. https://doi.org/10.1007/s11218-009-9108-0

Greenglass, E. R., Fiksenbaum, L., \& Burke, R. J. (1994). The relationship between social support and burnout over time in teachers. Journal of Social Behavior \& Personality, 9(2), 219-230.

Herman, K. C., Prewitt, S. L., Eddy, C. L., Savale, A., \& Reinke, W. M. (2020). Profiles of middle school teacher stress and coping: Concurrent and prospective correlates. Journal of School Psychology, 78, 54-68. https://doi.org/10.1016/j.jsp.2019.11.003

Hong, J. Y. (2012). Why do some beginning teachers leave the school, and others stay? Understanding teacher resilience through psychological lenses. Teachers and Teaching: Theory and Practice, 18(4), 417-440. https://doi.org/10.1080/13540602.2012.696044

Hurren, B. L. (2006). The effects of principals' humour on teachers' job satisfaction. Educational Studies, 32(4), 373-385. https://doi.org/10.1080/03055690600850321

Ingersoll, R. M. (2001). Teacher turnover and teacher shortages: An organizational analysis. American Educational Research Journal, 38(3), 499-534. https://doi.org/10.3102/00028312038003499

Johnson, S. E. (2003). Behavioural safety theory: Understanding the theoretical foundation. Professional Safety, 48(10), 39-44.

Johnson, Z. D., Goldman, Z. W., \& Claus, C. J. (2018). Why do students misbehave? An initial examination of antecedents to student misbehaviour. Communication Quarterly, 1-20. https://doi.org/10.1080/01463373.2018.1483958

Ju, C., Lan, J., Li, Y., Feng, W., \&You, X. (2015). The mediating role of workplace social support on the relationship between trait emotional intelligence and teacher burnout. Teaching and Teacher Education, 51, 58-67. https://doi.org/10.1016/j.tate.2015.06.001

Kahn, J. H., Schneider, K. T., Jenkins-Henkelman, T. M., \& Moyle, L. L. (2006). Emotional social support and job burnout among high-school teachers: Is it all due to dispositional affectivity? Journal of Organizational Behavior, 27(6), 793-807. https://doi.org/10.1002/job.397

Kasalak, G., \& Dağyar, M. (2020). The relationship between teacher self-efficacy and teacher job satisfaction: Ameta-analysis of the teaching and learning international survey (TALIS). Educational Sciences: Theory and Practice, 20(3), 16-33. https://doi.org/10.12738/jestp.2020.3.002 
Tomislava VIDIĆ, Marina ĐURANOVIĆ, Irena KLASNIĆ. Student misbehaviour, teacher self-efficacy, burnout and job satisfaction: Evidence from Croatia

PROBLEMS

OF EDUCATION

IN THE $21^{\text {st }}$ CENTURY

Vol. 79, No. 4, 2021

Kaynak, N. E. (2020). A close look at teachers' lives: Caring for the well-being of elementary teachers in the US. International Journal of Emotional Education, 12(1), 19-34. http:/oaji.net/articles/2020/4987-1588219239.pdf

Kengatharan, N. (2020). The effects of teacher autonomy, student behaviour and student engagement on teacher job satisfaction. Educational Sciences: Theory \& Practice, 20(4), 1-15. https://doi.org/10.12738/jestp.2020.4.001

Klassen, R., \& Chiu, M. M. (2010). Effects of teachers' self-efficacy and job satisfaction: teacher gender, years of experience, and job stress. Journal of Educational Psychology, 102(3), 741756. https://doi.org/10.1037/a0019237

Kokkinos, C. M. (2007). Job stressors, personality and burnout in primary school teachers. British Journal of Educational Psychology, 77(1), 229-243. https://doi.org/10.1348/000709905X90344

Kulinna, P., Cothran, D., \& Regualos, R. (2003). Development of an instrument to measure student disruptive behavior. Measurement in Physical Education and Exercise Science, 7(1), 25-41. https://doi.org/10.1207/S15327841MPEE0701_3

Kulinna, P., Cothran, D., \& Regualos, R. (2006). Teachers' reports of student misbehaviour in Physical Education. Research Quarterly for Exercise and Sport, 77(1), 32-40. https://doi.org/10.1080/02701367.2006.10599329

Kyriacou, C. (2011). Teacher stress: From prevalence to resilience. In J. Langan-Fox, \& C. L. Cooper (Eds.). New Horizons in Management (pp. 161-173). Cheltenham: Edward Elgar. https://doi.org/10.4337/9780857931153.00027

Lopes, J., Silva, E., Oliveira, C., Sass, D., Martin, N. (2017). Teacher's classroom management behavior and students' classroom misbehaviour: A study with 5th through 9th-grade students. Electronic Journal of Research in Educational Psychology, 15(3), 467-490. https://doi.org/10.25115/ejrep.43.17075

Ljubin Golub, T., Olčar, D., \& Bezak, S. (2016). Zadovoljstvo učitelja poslom: uloga agresivnog ponašanja i učiteljske povezanosti s učenicima [Teachers' satisfaction: The role of students' aggression and teachers' relatedness to students]. Napredak, 157(4), 437-458. https://hrcak.srce.hr/177213

Martin, A. J., \& Steinbeck, K. (2017). The role of puberty in students' academic motivation and achievement. Learning and Individual Differences, 53, 37-46. https://doi.org/10.1016/j.lindif.2016.11.003

Maslach, C., \& Jackson, S. E. (1981). The measurement of experienced burnout. Journal of Organizational Behavior, 2(2), 99-113. https://doi.org/10.1002/job.4030020205

Maslach, C., Jackson, S. E., \& Leiter, M. P. (2017). Maslach Burnout Inventory (4th ed.). Mind Garden.

Maslach, C., Schaufeli, W. B., \& Leiter, M. P. (2001). Job burnout. Annual Review of Psychology, 52(1), 397-422. https://doi.org/10.1146/annurev.psych.52.1.397

Meyers, S. (2003). Strategies to prevent and reduce conflict in college classrooms. College Teaching, 51(3), 94-98. https://doi.org/10.1080/87567550309596419

Özer, B., Bozkurt, N., \& Tuncay, A. (2014). Undesirable student behaviour and teachers' methods to deal with students in the classroom. Turkish Journal of Educational Studies, 1(2), 152-189.

Ross, S. W., Romer, N., \& Horner, R. H. (2012). Teacher well-being and the implementation of schoolwide positive behaviour interventions and supports. Journal of Positive Behavior Interventions, 14(2), 118-128. https://doi.org/10.1177/1098300711413820

Sadik, F., \& Yalcin, O. (2018). Examination of the views of high school teachers and students with regard to discipline perception and discipline problems. Journal of Education and Training Studies, 6(2), 97-113. https://doi.org/10.11114/jets.v6i2.2715

Sauter, S. L., Murphy, L. R., \& Hurrell, J. J. (1990). Prevention of work-related psychological disorders: A national strategy proposed by the National Institute for Occupational Safety and Health (NIOSH). American Psychologist, 45(10), 11461158. https://doi.org/10.1037/0003-066X.45.10.1146

Savas, A. C., Bozgeyik, Y., \& Eser, I. (2014). A study on the relationship between teacher self efficacy and burnout. European Educational Research Journal, 3(4), 159-166. https://doi.org/10.12973/eu-jer.3.4.159

Schwarzer, R., Schmitz, G. S., \& Tang, C. (2000). Teacher burnout in Hong Kong and Germany: A crosscultural validation of the Maslach Burnout Inventory. Anxiety, Stress \& Coping, 13(3), 309-326. https://doi.org/10.1080/10615800008549268 
Tomislava VIDIĆ, Marina ĐURANOVIĆ, Irena KLASNIĆ. Student misbehaviour, teacher self-efficacy, burnout and job satisfaction: Evidence from Croatia

PROBLEMS

OF EDUCATION

IN THE $21^{\text {st }}$ CENTURY Vol. 79, No. 4, 2021

672

Skaalvik, E. M. \& Skaalvik, S. (2010). Teacher self-efficacy and teacher burnout: A study of relations. Teaching and Teacher Education, 26 (4), 1059-1069. https://doi.org/10.1016/j.tate.2009.11.001

Skaalvik, E. M., \& Skaalvik, S. (2011). Teacher job satisfaction and motivation to leave the teaching profession: Relations with school context, feeling of belonging, and emotional exhaustion. Teaching and Teacher Education, 27(6), 1029-1038. https://doi.org/10.1016/j.tate.2011.04.001

Slišković, A., Burić, I., \& Knežević, I. (2016). Zadovoljstvo poslom i sagorijevanje na poslu kod učitelja: važnost podrške ravnatelja i radne motivacije [Job satisfaction and burnout in teachers: The importance of principal support and work motivation]. Društvena istraživanja, 25(3), 371-392. https://doi.org/10.5559/di.25.3.05

Soto, M., \& Rojas, O. (2019). Self-efficacy and job satisfaction as antecedents of citizenship behaviour in private schools. International Journal of Management in Education, 13(1), 82 96. https://doi.org/10.1504/IJMIE.2019.096472

Spector, P. E. (1997). Job satisfaction: Application, assessment, causes, and consequences. SAGE.

Stanton, J. M., Sinar, E. F., Balzer, W. K., Julian, A. L., Thoresen, P., Aziz, S., Fisher, G., G., Smith, P. C. (2001). Development of a compact measure of job satisfaction: The abridged job descriptive index. Educational and Psychological Measurement, 61(6), 1104-1122. https://doi.org/10.1177/001316440206200112

Sun, R. C. F., \& Shek, D. T. L. (2012). Student classroom misbehaviour: An exploratory study based on teachers' perceptions. The Scientific World Journal, 1-8. https://doi.org/10.1100/2012/208907

Toropova, A., Myrberg, E., \& Johansson, S. (2021). Teacher job satisfaction: The importance of school working conditions and teacher characteristics. Educational Review, 73(1), 71-97. https://doi.org/10.1080/00131911.2019.1705247

Tschannen-Moran, M., \& Woolfolk Hoy, A. (2001). Teacher efficacy: Capturing and elusive construct. Teaching and Teacher Education, 17(7), 783-805. https://doi.org/10.1016/S0742-051X(01)00036-1

Tsouloupas, C. N., Carson, R. L., \& MacGregor, S. K. (2014). The development of high school teachers' efficacy in handling student misbehaviour (TEHSM). The Journal of Educational Research, 107(3), 230-240. https://doi.org/10.1080/00220671.2013.788992

Watkins, C., \& Wagner, P. (2000). Improving School Behaviour. Paul Chapman.

Wei, M. H. (2013). Multiple abilities and subjective well-being of Taiwanese kindergarten children. Social Behavior and Personality, 41(1), 7-16. https://doi.org/10.2224/sbp.2013.41.1.7

Weiss, H. (2002). Deconstructing job satisfaction: Separating evaluations, beliefs, and affective experiences. Human Resource Management Review, 12(2), 173-194. https://doi.org/10.1016/S1053-4822(02)00045-1

Zee, M., \& Koomen, H. M. (2016). Teacher self-efficacy and its effects on classroom processes, student academic adjustment, and teacher well-being: A synthesis of 40 years of research. Review of Educational Research, 86(4), 981-1015. https://doi.org/10.3102/0034654315626801

Received: June 17, 2021

Accepted: August 04, 2021 
Tomislava VIDIĆ, Marina ĐURANOVIĆ, Irena KLASNIĆ. Student misbehaviour, teacher self-efficacy, burnout and job satisfaction: Evidence from Croatia

PROBLEMS

OF EDUCATION

IN THE $21^{\text {st }}$ CENTURY

Vol. 79, No. 4, 2021

Cite as: Vidić, T., Đuranović, M., \& Klasnić, I. (2021). Student misbehaviour, teacher selfefficacy, burnout and job satisfaction: Evidence from Croatia. Problems of Education in the $21^{s t}$ Century, 79(4), 657-673. https://doi.org/10.33225/pec/21.79.657

\begin{tabular}{|ll|}
\hline Tomislava Vidić & PhD, Lecturer, Primary School Remete, Remete 99, 10000 Zagreb, Croatia. \\
& E-mail: tomislava.vidic@zg.t-com.hr \\
& ORCID: https://orcid.org/0000-0003-2040-2667 \\
\hline Marina Đuranović & PhD, Associate Professor, University of Zagreb, Faculty of Teacher \\
& Education, Savska 77, 10 000, Zagreb, Croatia. \\
& E-mail: marina.duranovic@ufzg.hr \\
& ORCID: https://orcid.org/0000-0001-7199-5488 \\
\hline Irena Klasnić & PhD, Assistant Professor, University of Zagreb, Faculty of Teacher \\
(Corresponding author) & Education, Savska 77, 10 000, Zagreb, Croatia. \\
& E-mail: irena.klasnic@ufzg.hr \\
ORCID: https://orcid.org/0000-0002-0315-3104
\end{tabular}

